\title{
Effectiveness of two sampling methods used for collecting Ichneumonidae (Hymenoptera) in the Cabañeros National Park (Spain)
}

\author{
Marina MAZÓN and SANTIAGo BORDERA \\ Instituto de Investigación de Biodiversidad CIBIO, Universidad de Alicante, Ap. Correos 99, 03080-Alicante, Spain; \\ e-mails: mazon@ua.es, eukarya@hotmail.com,s.bordera@ua.es
}

Key words. Ichneumonidae, Malaise trap, Moericke yellow trap, richness estimators, overlap indices, habitat structure, Cabañeros National Park

\begin{abstract}
When estimating the species richness of a taxonomic group in a specific area, the choice of the trapping method is extremely important. In this study the effectiveness of Malaise and Moericke yellow pan traps for collecting flying Ichneumonidae was compared. Samples were collected in 5 habitats in the Cabañeros National Park: pastureland, shrubland and three types of woodland. Two traps of each type were placed in each habitat, and samples collected over a period of one year, replacing the pots every 20 days. The study focused on eleven subfamilies of Ichneumonidae. The results showed that the composition of the Ichneumonidae in the catches of the two traps differed. Malaise traps were more effective in collecting Ichneumonidae in all habitats, but especially in the ash woodland. Moericke traps yielded the most abundant catches in open areas with a wider field of vision. The subfamily Orthocentrinae occurred more frequently in the Moericke yellow traps. The Ichneumonidae caught by both trapping methods differed, especially in the relative abundance of the most common species. When compiling an inventory of species it is extremely important to use a combination of both trapping methods.
\end{abstract}

\section{INTRODUCTION}

Knowledge and conservation of biodiversity are a challenge for those of us who are responsible for the environmental legacy for future generations. One of the most effective ways of preserving biodiversity is legal protection of habitats in areas such as national parks. Cabañeros is a vast area in central Spain, declared a National Park in 1995. The area has retained centuries-old traditional land use activities, such as shepherding or apiculture, which together with the nearly total absence of human settlements in this region, makes Cabañeros a very interesting study area. So far, investigations of the fauna of this National Park have focused on vertebrates (García, 1997), with only few studies on insects (Jiménez-Valverde et al., 2004; Ricarte \& Marcos-García, 2008).

The Ichneumonidae is the largest family within the Hymenoptera, probably the most diverse order in the world (Grissell, 1999). They are important in ecosystem dynamics: since they are parasitoids of holometabolous insects, and regulate their hosts' population. Patterns in the biodiversity of Ichneumonidae may reflect that of other groups lower in the food chain. But first of all, an appropriate choice of trapping methods is essential when estimating the richness of such a diverse insect group in a specific area.

For collecting insects, entomologists use two types of traps: passive and active traps. The former intercept insects randomly, while the latter use specific attractants (odours, colours, forms, etc.) to attract insects more selectively. Examples of passive traps include the Malaise trap for insects flying at around ground level, pitfall traps for ground-dwelling insects, or window traps for insects flying high above the ground. Attraction traps include the Moericke trap (insects are attracted by colour), light traps (for nocturnal insects) or baited traps, which attract insects with similar trophic habits (Marcos-García, 2004).

Malaise traps are widely used for catching flying insects (Matthews \& Matthews, 1970; Marinoni \& Dutra, 1997; Steinbauer et al., 2000; Vas et al., 2001; Ganho \& Marinoni, 2003), especially Diptera and Hymenoptera (Nieves-Aldrey \& Rey del Castillo, 1991; Selfa et al., 2003). In fact, Malaise traps are a more effective sampling method for non-formicid Hymenoptera compared to the Moericke pan traps (Darling \& Packer, 1988; Campbell \& Hanula, 2007; Leirana-Alcocer \& GonzálezMoreno, 2007), other interception traps (Campos et al., 2000) and various traps covering many potential niches (Kitching et al., 2001). As a consequence, they are the most commonly used traps in studies of Ichneumonidae (Anento \& Selfa, 1997a, b; Kumagai \& Graf, 2000, 2002; Skillen et al., 2000; Sääksjärvi et al., 2004). The Moericke yellow traps are commonly used for sampling aphids (Moericke, 1950, 1951), flies or bees (Duviar \& Pollet, 1973; Monsevičius, 2004; Laubertie et al., 2006; Souza \& Campos, 2008), but, although less effective than the Malaise traps, are also used for collecting Ichneumonidae as well (Sawoniewicz, 1986, 1995; Hilszczański, 1998; Onody \& Penteado-Dias, 2002) because they collect species not caught by Malaise traps (Delfín \& Burgos, 2000; Leirana-Alcocer \& González-Moreno, 2007).

Of all these studies, none used quantitative and qualitative data to compare the effectiveness of different kinds of traps for sampling Ichneumonidae in various habitats. The aims of this paper are (1) to compare the effectiveness, in terms of abundance, species richness and sex 
TABLE 1. Description of habitats and location of trapping sites. Spanish names of habitats in quotation marks. $M=M a l a i s e$ trap; Mo $=$ Moericke trap.

\begin{tabular}{|c|c|c|c|c|c|c|}
\hline \multicolumn{3}{|c|}{ Habitat } & \multicolumn{2}{|c|}{ Trap } & \multicolumn{2}{|c|}{ Coordinates (degrees, minutes, seconds) } \\
\hline Name & Brief description of vegetation & Dominant plants & & & $\mathrm{X}$ & $\mathrm{Y}$ \\
\hline \multirow{4}{*}{$\begin{array}{l}\text { Cork-oak } \\
\text { woodland } \\
\text { "Alcornocal" }\end{array}$} & \multirow{4}{*}{$\begin{array}{l}\text { Sanguisorbo hybridae-Querceto } \\
\text { suberis sigmetum association. } \\
\text { Subhumid mediterranean forest } \\
\text { with dense shrubby layer }\end{array}$} & \multirow{4}{*}{$\begin{array}{l}\text { Quercus suber, Sangui- } \\
\text { sorba agrimonioides, } \\
\text { Phyllirea angustifolia, } \\
\text { Erica arborea }\end{array}$} & $\mathrm{M}$ & 01 & $4^{\circ} 36^{\prime} 14.5^{\prime \prime} \mathrm{W}$ & $39^{\circ} 26^{\prime} 55.4^{\prime \prime} \mathrm{N}$ \\
\hline & & & & 02 & $4^{\circ} 36^{\prime} 10.1^{\prime \prime} \mathrm{W}$ & $39^{\circ} 26^{\prime} 50.7^{\prime \prime} \mathrm{N}$ \\
\hline & & & Mo & 01 & $4^{\circ} 36^{\prime} 15.4^{\prime \prime} \mathrm{W}$ & $39^{\circ} 26^{\prime} 56.3^{\prime \prime} \mathrm{N}$ \\
\hline & & & & 02 & $4^{\circ} 36^{\prime} 12.0^{\prime \prime} \mathrm{W}$ & $39^{\circ} 26^{\prime} 51.9^{\prime \prime} \mathrm{N}$ \\
\hline \multirow{4}{*}{$\begin{array}{l}\text { Ash woodland } \\
\text { "Fresneda" }\end{array}$} & \multirow{4}{*}{$\begin{array}{l}\text { Ficario-Faxineto angustifoliae } \\
\text { sigmetum association. } \\
\text { Open riverbank deciduous forest }\end{array}$} & \multirow{4}{*}{$\begin{array}{l}\text { Fraxinus angustifolia, } \\
\text { Rubus ulmifolius, } \\
\text { Cistus ladanifer }\end{array}$} & $\mathrm{M}$ & 01 & $4^{\circ} 33^{\prime} 48.1^{\prime \prime} \mathrm{W}$ & $39^{\circ} 26^{\prime} 54.6^{\prime \prime} \mathrm{N}$ \\
\hline & & & & 02 & $4^{\circ} 33^{\prime} 49.6^{\prime \prime} \mathrm{W}$ & $39^{\circ} 26^{\prime} 50.3^{\prime \prime} \mathrm{N}$ \\
\hline & & & Mo & 01 & $4^{\circ} 33^{\prime} 48.8^{\prime \prime} \mathrm{W}$ & $39^{\circ} 26^{\prime} 52.4^{\prime \prime} \mathrm{N}$ \\
\hline & & & & 02 & $4^{\circ} 33^{\prime} 51.8^{\prime \prime} \mathrm{W}$ & $39^{\circ} 26^{\prime} 49.3^{\prime \prime} \mathrm{N}$ \\
\hline \multirow{4}{*}{$\begin{array}{l}\text { Shrubland } \\
\text { "Matorral" }\end{array}$} & \multirow{4}{*}{$\begin{array}{c}\text { Phillyreo-Arbutetum } \\
\text { association. } \\
\text { Dense shubland with few sparse } \\
\text { trees }\end{array}$} & \multirow{4}{*}{$\begin{array}{c}\text { Arbutus unedo, Viburnum } \\
\text { tinus, Erica arborea, } \\
\text { Erica scoparia, Cistus } \\
\text { ladanifer }\end{array}$} & $\mathrm{M}$ & 01 & $4^{\circ} 28^{\prime} 25.2^{\prime \prime} \mathrm{W}$ & $39^{\circ} 21^{\prime} 32.6^{\prime \prime} \mathrm{N}$ \\
\hline & & & & 02 & $4^{\circ} 28^{\prime} 37.3^{\prime \prime} \mathrm{W}$ & $39^{\circ} 21^{\prime} 42.0^{\prime \prime} \mathrm{N}$ \\
\hline & & & Mo & 01 & $4^{\circ} 28^{\prime} 23.6^{\prime \prime} \mathrm{W}$ & $39^{\circ} 21^{\prime} 32.8^{\prime \prime} \mathrm{N}$ \\
\hline & & & & 02 & $4^{\circ} 28^{\prime} 36.8^{\prime \prime} \mathrm{W}$ & $39^{\circ} 21^{\prime} 44.2^{\prime \prime} \mathrm{N}$ \\
\hline \multirow{4}{*}{$\begin{array}{l}\text { Pyrenean-oak } \\
\text { woodland } \\
\text { "Melojar" }\end{array}$} & \multirow{4}{*}{$\begin{array}{l}\text { Arbuto unedonis-Quercetum } \\
\text { pyrenaicae association. } \\
\text { Humid old deciduous forest }\end{array}$} & \multirow{4}{*}{$\begin{array}{l}\text { Quercus pyrenaica, } \\
\text { Quercus faginea, Erica } \\
\text { arborea, Phyllirea } \\
\text { angustifolia }\end{array}$} & $\mathrm{M}$ & 01 & $4^{\circ} 29^{\prime} 24.9^{\prime \prime} \mathrm{W}$ & $39^{\circ} 22^{\prime} 31.8^{\prime \prime} \mathrm{N}$ \\
\hline & & & & 02 & $4^{\circ} 29^{\prime} 16.1^{\prime \prime} \mathrm{W}$ & $39^{\circ} 22^{\prime} 26.8^{\prime \prime} \mathrm{N}$ \\
\hline & & & Mo & 01 & $4^{\circ} 29^{\prime} 25.6^{\prime \prime} \mathrm{W}$ & $39^{\circ} 22^{\prime} 33.3^{\prime \prime} \mathrm{N}$ \\
\hline & & & & 02 & $4^{\circ} 29^{\prime} 20.0^{\prime \prime} \mathrm{W}$ & $39^{\circ} 22^{\prime} 27.7^{\prime \prime} \mathrm{N}$ \\
\hline \multirow{4}{*}{$\begin{array}{l}\text { Pastureland } \\
\text { "Raña" }\end{array}$} & \multirow{4}{*}{$\begin{array}{c}\text { Poa bulbosae-Trifolietum } \\
\text { subterranei association. } \\
\text { Open abandoned pastureland } \\
\text { with few sparse trees }\end{array}$} & \multirow{4}{*}{$\begin{array}{l}\text { Quercus rotundifolia, } \\
\text { Trifolium subterraneum, } \\
\text { Lolium rigidum, } \\
\text { Poa bulbosa }\end{array}$} & $\mathrm{M}$ & 01 & $4^{\circ} 19^{\prime} 28.0^{\prime \prime} \mathrm{W}$ & $39^{\circ} 18^{\prime} 57.4^{\prime \prime} \mathrm{N}$ \\
\hline & & & & 02 & $4^{\circ} 19^{\prime} 27.8^{\prime \prime} \mathrm{W}$ & $39^{\circ} 19^{\prime} 23.5^{\prime \prime} \mathrm{N}$ \\
\hline & & & Mo & 01 & $4^{\circ} 19^{\prime} 31.6^{\prime \prime} \mathrm{W}$ & $39^{\circ} 18^{\prime} 56.4^{\prime \prime} \mathrm{N}$ \\
\hline & & & & 02 & $4^{\circ} 19^{\prime} 27.9^{\prime \prime} \mathrm{W}$ & $39^{\circ} 19^{\prime} 22.6^{\prime \prime} \mathrm{N}$ \\
\hline
\end{tabular}

ratio, of two traps commonly used for collecting Ichneumonidae, Malaise traps and Moericke yellow pan traps, and (2) to check differences in the Ichneumonidae communities collected by both trapping methods. We are interested in whether habitat or other factors such as sex or subfamily influence the traps effectiveness, in the context of the Cabañeros National Park.

\section{MATERIAL AND METHODS}

\section{Study area}

The Cabañeros National Park is a protected area of about 40,000 ha, located south of the Toledo Mountains, in the Castilla-La Mancha Autonomous Community (Spain). It is characterised by mountainous areas alternating with vast extensions of pastureland called "raña". Located in the Mesomediterranean subhumid bioclimatic belt, it experiences a dry summer and wet winter. The annual mean temperatures range $13-16^{\circ} \mathrm{C}$, and rainfall is usually above $500 \mathrm{~mm}$ per year. The habitats included in this study are described in Table 1 .

\section{Sampling}

This study was carried out in five representative habitats in the Park. The insects were sampled using Malaise and Moericke traps: two traps of each type were placed in each habitat (Table 1). They were separated by a distance varying from 120 to 815 $\mathrm{m}$ (depending on the area of the habitat), with a total of $10 \mathrm{Mal}-$ aise and 10 Moericke yellow traps. Sampling took place over a period of one year, from March 2004 to April 2005. The traps were replaced every approximately 20 days, resulting in 18 sampling periods for each trap.

All specimens of Ichneumonidae were identified to the subfamily level. Subfamilies Anomaloninae, Banchinae, Cremastinae, Cryptinae (tribe Cryptini), Ctenopelmatinae, Diplazontinae, Metopiinae, Orthocentrinae, Pimplinae, Tersilochinae and Try- phoninae were determined to species level and included in the analyses of sex ratio, species richness and Ichneumonidae communities, since we are experienced in the identification of these groups.

\section{Traps}

The Townes style Malaise trap in white was used (Townes, 1972), with the addition of a plastic grid with a mesh size of 1 $\mathrm{cm}$, just before the entrance to the collecting pot. This prevented the capture of big insects such as butterflies and therefore any damage to their populations. Collecting pots were filled with $70 \%$ ethanol.

Moericke yellow traps were $26 \mathrm{~cm}$ in diameter and $11 \mathrm{~cm}$ deep. They were hung from trees at a height of 2-3 m above ground level and filled with $70 \%$ ethyleneglycol and few drops of detergent added. After each sampling period, all the material was transferred to $70 \%$ alcohol, where it was stored until processed.

\section{Data analyses}

Before comparing trap catches, the similarity of the catches of the pairs of traps placed in each habitat was tested in order to decide if they could be used as replicates. A principal components analysis was conducted. Using the relative frequencies of all the species studied, the analysis combines all data into new factors and traps are represented in a 2D plot according to the new combined variables.

To compare the effectiveness of both traps for catching Ichneumonidae wasps in terms of abundance, the non-parametric Kruskal-Wallis analysis was used (Siegel \& Castellan, 1988), with the habitat type as the independent factor. An ad-hoc multiple comparison of mean ranks was used to reveal differences between individual habitats. The Kruskal-Wallis analyses compared: (1) differences in numbers of individuals collected by both methods in the five habitats, and (2) differences in numbers of each sex between traps. The independent factor was habitat 

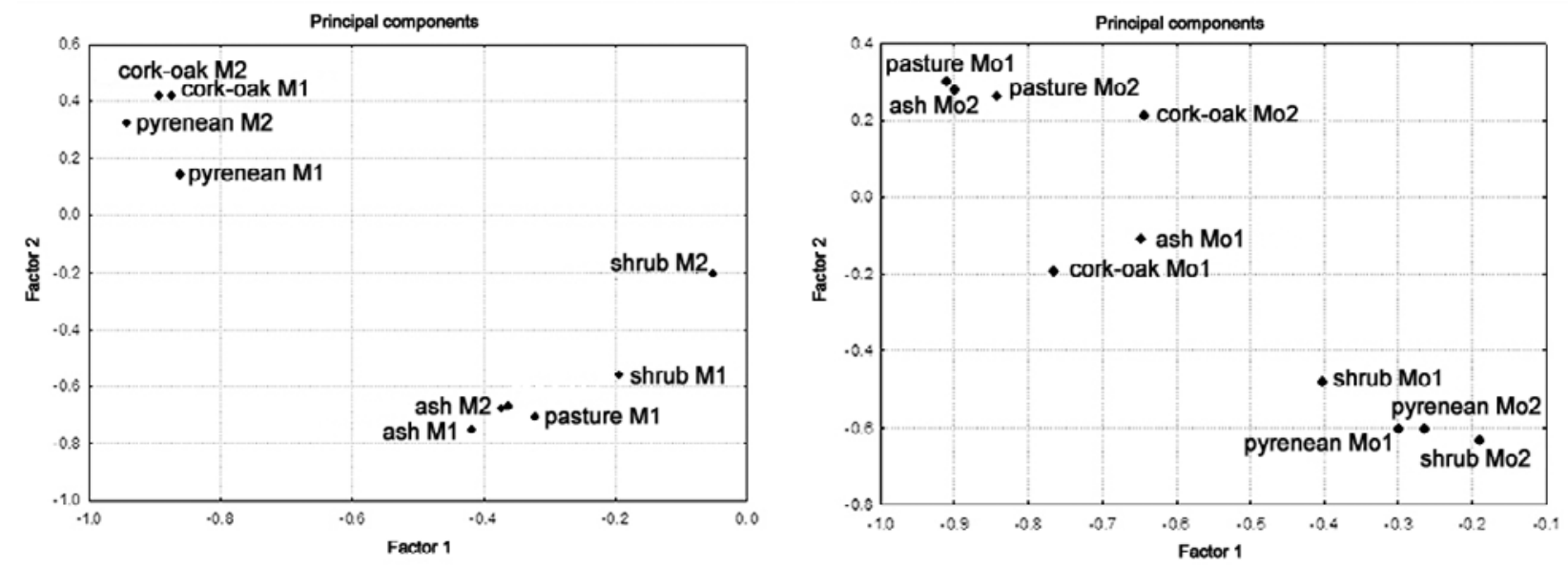

Fig. 1. Factor analyses of Malaise (left) and Moericke (right) trap catches. Habitat types are labelled with abbreviated names.

type for the former and sex for the latter. The sex ratio of every subfamily studied occurring in every habitat, regardless of trapping method, was also calculated.

A canonical correspondence analysis (CCA) was performed in order to survey whether the different subfamilies responded to both trapping methods in the same way in every habitat. This statistic determines the multivariate relationship between the species composition of samples and external predictors of the samples, i.e. trap type and habitat.

The quality of the sampling was tested using a species accumulation curve and richness estimators. The accumulation curve reflects the rate of recording new species during the sampling period. As the curve approaches the upper asymptote it indicates that nearly all the species have been sampled and, as a consequence, sampling is complete (Moreno \& Halffter, 2000; Fraser et al., 2007, 2008). Singletons and doubletons are those species represented by just one or two specimens, respectively, and the crossing of both curves indicates a sufficient sampling effort (Sääksjärvi et al., 2004). Non-parametric estimators, that predict the number of non-found species from the relative abundance of rare species, were also used (Longino et al., 2002). This allows one to establish the percentage of species caught according to the total regional richness given by these estimators. The estimators used in this work were ICE, the best accepted one (Longino et al., 2002), and Chao 2 and Jackknife 1, already used for Hymenoptera (Braud et al., 2003).

To compare species richness, the data for the subfamilies mentioned above were compared by a bootstrap re-sampling process and two overlapping indices. The bootstrap is a nonparametric analysis that estimates the variance of the sample

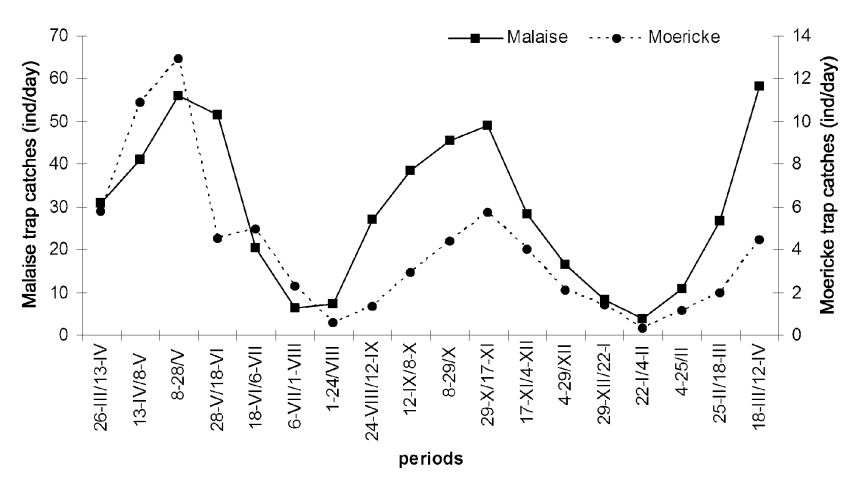

Fig. 2. Annual trends in the numbers of Ichneumonidae caught by both trapping methods. median, so that it establishes a confidence interval for species richness (Moreno et al., 2008). It can be used to compare richness of samples when true replicates are absent. To check the species composition of the Ichneumonidae collected by both traps, two overlapping indices were calculated: Morisita-Horn, which takes into account the species present in each sample and their abundance, and Sorensen, that only considers presence/absence data. These indices indicate the species caught by both trapping methods, fluctuating between 0 and 1 , which means no to complete overlap. This may indicate the level of complementarity of Malaise and Moericke traps.

Statistical analyses were performed using the software Statistica version 6.1. CCA statistic was developed with Biplot version 1.1 (Virginia Tech). The bootstrap was conducted using StatsDirect version 2.6.9, with 2000 randomizations and $95 \%$ confidence intervals. The overlap indices and non-parametric estimators were calculated using EstimateSWin7.5 (Colwell, 2005).

\section{RESULTS}

\section{Replicates}

The factor analysis (Fig. 1) showed that the samples from the pairs of Malaise traps placed in pastureland, ash and cork-oak woodland were very similar to each other. Shrubland and Pyrenean-oak woodland samples were more dissimilar. Those from the pairs of Moericke traps were, in general, rather dissimilar, except for the pastureland and Pyrenean-oak woodland samples. Occasionally, the variability between different habitats seemed to be lower than that between the catches of pairs of traps. Thus, the samples from pairs of traps could not be considered as replicates for statistical analysis, so the data from both were pooled. As a consequence, there was just one sample for each trap type in each habitat.

Therefore, for the Kruskal-Wallis analyses and CCA, the data from the temporal periods were used as replicates, a total of 16 and 14 periods, respectively (in periods 6 and 7 several traps were damaged and samples lost; periods 10 and 13 were excluded from the CCA because no specimens were present in some samples). The effect of seasonality was assumed to be the same in all habitats, therefore the results must be interpreted with extreme care. As the sampling periods were not of the 


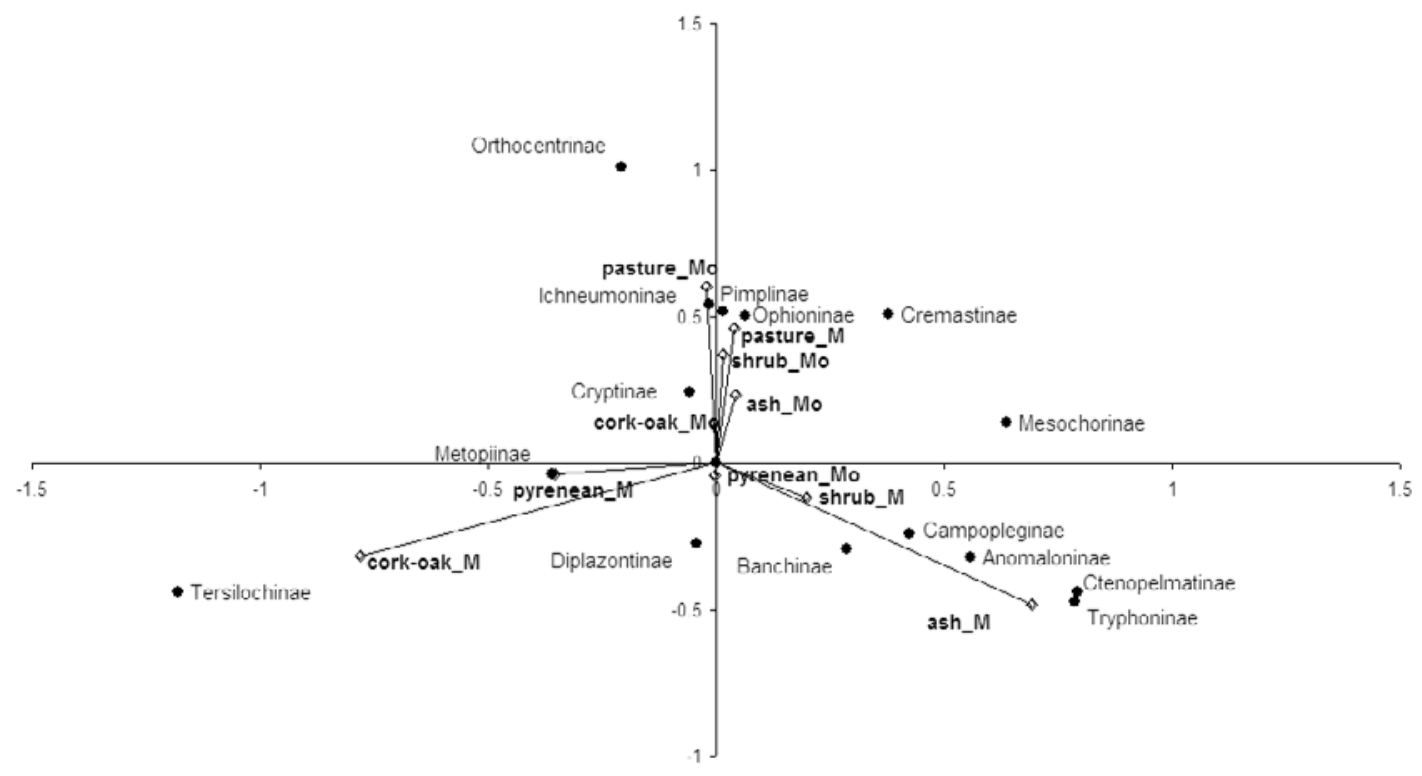

Fig. 3. Biplot from the CCA analysis. Black dots indicate subfamilies, while vectors represent habitat and trap type, labelled with an abbreviated name for the habitat and initials of trap type: $\mathrm{M}$ - Malaise trap; Mo - Moericke trap.

same length, data were standardised in terms of individuals collected per day (ind/day).

\section{Abundances}

Total catches

A total of 12,748 ichneumonid wasps were caught, 11,215 by Malaise and 1,534 by Moericke yellow traps, i.e. nearly $88 \%$ of the total catch was caught by the interception traps (Appendix 1). The annual trend in the numbers caught (Fig. 2) showed that there were two peaks of activity: the first one in spring (May) and second in autumn (October). Both peaks were of similar size for the Malaise catches, but the spring was greater than the autumn peak for the Moericke trap catches.

According to the Kruskal-Wallis analysis performed on the total number of Ichneumonidae, Malaise traps were significantly more effective in ash woodland than in shrubland $(\mathrm{H}=16.74, \mathrm{p}<0.002)$. Moericke traps, however, caught significantly more in pastureland and shrubland than in cork-oak woodland $(\mathrm{H}=23.18, \mathrm{p}<0.0001)$.

\section{Subfamilies}

Appendix 1 shows the percentages of the 19 subfamilies of Ichneumonidae collected. Cryptinae was the most common subfamily, making up $29 \%$ of the total catch, followed by Campopleginae (19\%), Banchinae (16\%) and Tersilochinae (14\%). The analysis of relative abundances revealed that the percentages were practically identical in Malaise trap catches, but not in Moericke trap catches: Orthocentrinae increased in percentage from 3 to $22 \%$, while Banchinae and Tersilochinae decreased to 6 and $3 \%$, respectively. Thus, the effectiveness of Malaise and Moericke traps depends on the subfamily and habitat studied. The Malaise trap, however, was more effective in all situations.

CCA analysis was performed for all subfamilies collected, excluding those for which less than 50 individuals caught (Fig. 3). This analysis arranged the samples according to trap rather than habitat, indicating that the Ichneumonidae collected by both trapping methods were

TABLE 2. Sex ratio (males/females) for each subfamily in each habitat. Asterisks indicate no males caught, and the number corresponds to the number of females caught. Apostrophes indicate no females caught, with only the number of males being specified.

\begin{tabular}{lcccccc}
\hline & $\begin{array}{c}\text { Cork-oak } \\
\text { woodland }\end{array}$ & Ash woodland & Shrubland & $\begin{array}{c}\text { Pyrenean-oak } \\
\text { woodland }\end{array}$ & Pastureland & Total \\
\hline Anomaloninae & $4^{*}$ & 0.02 & 0.11 & $8^{*}$ & $8^{*}$ & 0.02 \\
Banchinae & 0.81 & 0.97 & 0.52 & 0.86 & 1.72 & 0.92 \\
Cremastinae & 0.50 & 0.11 & 0.40 & 3 & 0.36 & 0.30 \\
Cryptini & 3.15 & 1.51 & 2.29 & 1.93 & 1.31 & 1.72 \\
Ctenopelmatinae & $1^{*}$ & 2.26 & 1 & 2.22 & 0.25 & 1.97 \\
Diplazontinae & $2^{*}$ & $30^{*}$ & 0 & 0.02 & $3 *$ & 0.01 \\
Metopiinae & 0.32 & 0.67 & 1.15 & 0.20 & 0.38 & 0.40 \\
Orthocentrinae & 0.25 & 1.36 & 2.45 & 0.12 & 3.34 & 0.98 \\
Pimplinae & 0.11 & 0.49 & 0.21 & 1.73 & 0.70 & 0.70 \\
Tersilochinae & 2.99 & 0.43 & 0.15 & 1.65 & 0.88 & 1.83 \\
Tryphoninae & 1 & 4.94 & 1, & 5 & 5 & 5.05 \\
\hline
\end{tabular}




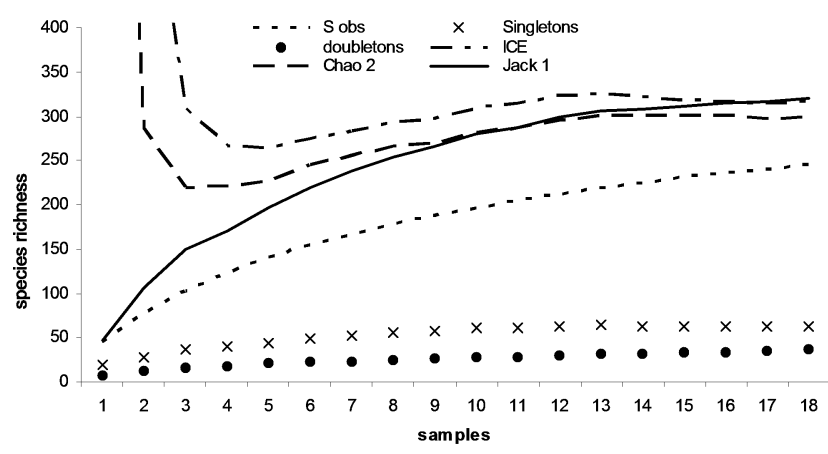

Fig. 4. Accumulation curve of the numbers of species captured in the five habitats by both Malaise and Moericke traps. S obs - observed richness; singletons - species represented by only one specimen; doubletons - species represented by just two specimens; ICE, Chao2 and Jack1 are the estimators.

clearly different. Some subfamilies were closely associated with a trapping method or habitat type, e.g. Tersilochinae with Malaise traps and cork-oak woodland or Orthocentrinae with Moericke traps and pastureland.

\section{Sex ratio}

Sex ratio (Table 2) was clearly biased towards females in most subfamilies, especially Anomaloninae and Diplazontinae. Only in Tryphoninae and Cryptini did males prevail over females in all habitats. The ratio in Tersilochinae and Ctenopelmatinae seemed to depend on the habitat, with total proportions biased towards males. In Banchinae and Orthocentrinae, the ratios based on the total catches were nearly $1: 1$, but the proportions varied according to the habitat. A Kruskal-Wallis test performed to check for bias in sex ratio due to the trapping method showed that differences were not associated with trap
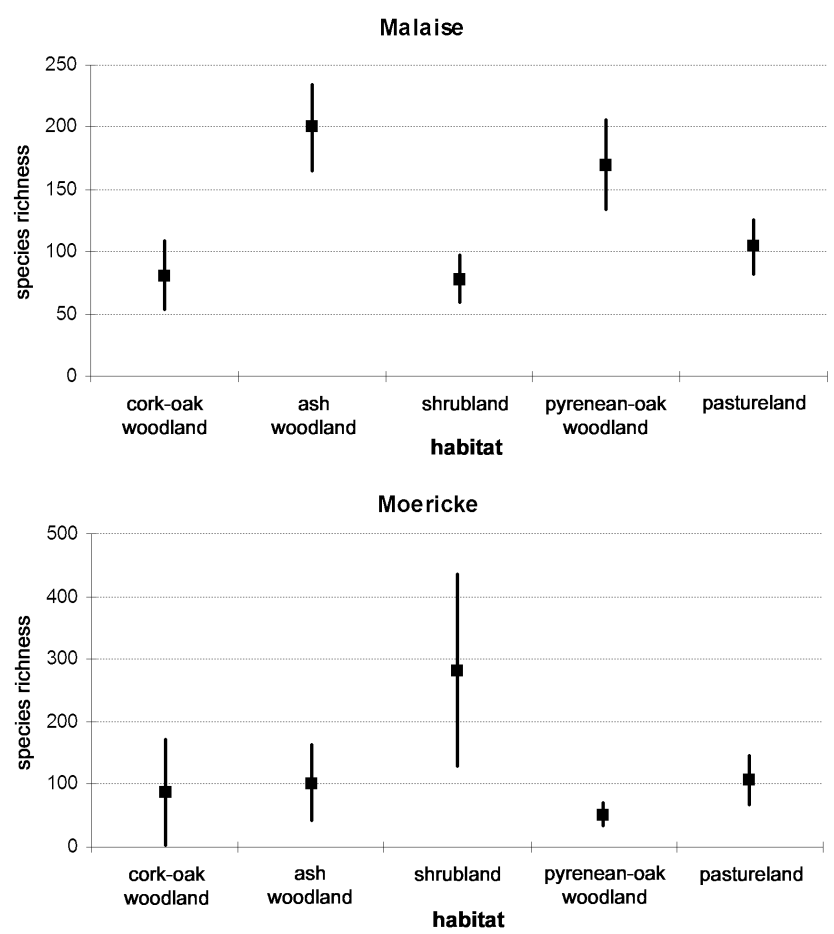

Fig. 5. Estimated species richness for each habitat (squares) and the confidence intervals obtained from the bootstrap process, performed separately for each trapping method.

design. There were a few significant differences, mostly associated with differences in sex ratio independent of trap type.

\section{Species richness}

The accumulation curves for the five habitats and both trap types showed that after one year of sampling the

TABLE 3. Percentages of the total species richness caught predicted by estimators. The Classic Chao 2 was only calculated when it was recommended by the software.

\begin{tabular}{lccccc}
\hline \multirow{2}{*}{ Habitat } & Trap & \multicolumn{4}{c}{ Richness estimators } \\
\cline { 3 - 5 } all & both & ICE & Chao2 & Cl. Chao2 & Jack1 \\
& Malaise & 77.39 & 81.87 & 76.43 \\
& Moericke & 75.04 & 77.19 & 75.29 \\
cork-oak & both & 50.70 & 69.03 & 66.64 & 68.66 \\
woodland & Malaise & 50.57 & 63.93 & 59.89 & 65.41 \\
& Moericke & 34.60 & 57.09 & 51.82 & 58.54 \\
\hline \multirow{4}{*}{ ash woodland } & both & 69.37 & 50.66 & 75.36 & 71.19 \\
& Malaise & 67.08 & 71.53 & 73.40 & 62.75 \\
\hline \multirow{3}{*}{ shrubland } & Moericke & 42.07 & 49.05 & 69.28 & 70.43 \\
& both & 68.86 & 70.96 & 41.97 & 72.75 \\
pyrenean-oak & Malaise & 75.68 & 78.45 & & 60.07 \\
woodland & Moericke & 36.76 & 36.28 & 30.98 & 68.96 \\
& both & 60.74 & 63.01 & 60.22 & 71.19 \\
pastureland & Malaise & 66.76 & 69.82 & 67.12 & 60.63 \\
& Moericke & 36.80 & 50.66 & 44.24 & 72.15 \\
\hline
\end{tabular}


TABLE 4. Number of species caught of each subfamily in each habitat only by Malaise traps ("Malaise"), only by Moericke traps ("Moericke") and by both kinds of traps ("both").

\begin{tabular}{|c|c|c|c|c|c|c|c|c|c|c|c|c|}
\hline & & 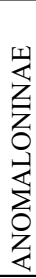 & 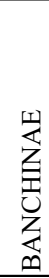 & 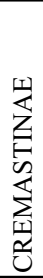 & 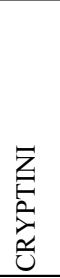 & 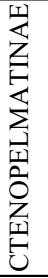 & 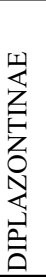 & & 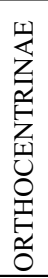 & 崩 & 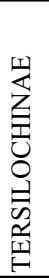 & 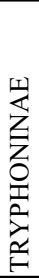 \\
\hline \multirow{3}{*}{$\begin{array}{l}\text { cork-oak } \\
\text { woodland }\end{array}$} & Malaise & 1 & 10 & 1 & 9 & 1 & 1 & 5 & 5 & 3 & 3 & 1 \\
\hline & Moericke & 0 & 1 & 1 & 0 & 0 & 0 & 0 & 3 & 2 & 0 & 0 \\
\hline & both & 0 & 1 & 0 & 1 & 0 & 0 & 0 & 5 & 1 & 1 & 0 \\
\hline \multirow{3}{*}{$\begin{array}{l}\text { ash } \\
\text { woodland }\end{array}$} & Malaise & 3 & 18 & 7 & 34 & 16 & 5 & 5 & 4 & 10 & 10 & 5 \\
\hline & Moericke & 0 & 1 & 0 & 4 & 2 & 0 & 1 & 1 & 2 & 0 & 0 \\
\hline & both & 1 & 7 & 1 & 1 & 3 & 0 & 0 & 9 & 0 & 1 & 1 \\
\hline \multirow{3}{*}{ shrubland } & Malaise & 2 & 7 & 3 & 9 & 4 & 0 & 1 & 2 & 4 & 4 & 0 \\
\hline & Moericke & 1 & 3 & 0 & 5 & 1 & 0 & 2 & 9 & 8 & 3 & 1 \\
\hline & both & 0 & 6 & 2 & 5 & 0 & 0 & 2 & 3 & 3 & 1 & 0 \\
\hline \multirow{3}{*}{$\begin{array}{l}\text { pyrenean-oak } \\
\text { woodland }\end{array}$} & Malaise & 3 & 20 & 3 & 19 & 5 & 2 & 8 & 17 & 12 & 3 & 3 \\
\hline & Moericke & 0 & 5 & 0 & 3 & 4 & 0 & 2 & 1 & 0 & 1 & 0 \\
\hline & both & 0 & 5 & 0 & 3 & 1 & 0 & 0 & 1 & 1 & 5 & 1 \\
\hline \multirow{3}{*}{ pastureland } & Malaise & 3 & 7 & 3 & 10 & 2 & 1 & 3 & 1 & 2 & 8 & 1 \\
\hline & Moericke & 0 & 3 & 0 & 3 & 2 & 0 & 1 & 3 & 4 & 0 & 2 \\
\hline & both & 0 & 4 & 2 & 11 & 0 & 1 & 2 & 8 & 5 & 3 & 0 \\
\hline
\end{tabular}

curves did not become asymptotic, and those for singletons and doubletons did not cross (Fig. 4). Nevertheless, according to the most optimistic estimator (Table 3), nearly $82 \%$ of the species in the 11 subfamilies studied was collected, a percentage greater than that collected by the Malaise $(77 \%)$ or Moericke $(69 \%)$ traps. Regarding the habitats, the estimators indicate that cork-oak wood-
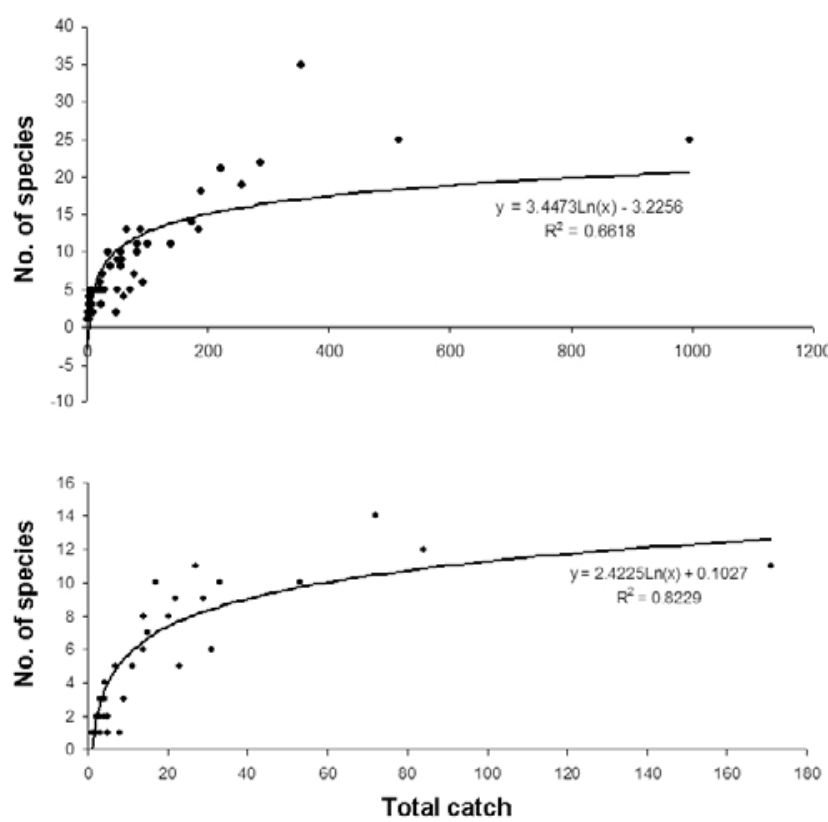

Fig. 6. Logarithmic function showing the relationship between total catch and number of species in the Malaise trap (up) and Moericke trap (down) samples.

land was poorly sampled, while $80 \%$ of species in pastureland was sampled. In all cases, the Moericke were less effective than Malaise traps, suggesting that more Moericke traps were needed.

The bootstrap process showed that Malaise traps catches in ash and Pyrenean-oak woodland were significantly the richest (Fig. 5). The samples collected by Moericke traps had wider confidence intervals and lower averages than those from the Malaise traps. Richness in

TABLE 5. Values for the Sorensen and Morisita-Horn indices comparing Malaise and Moericke trap catches of each subfamily studied in each habitat. The total values are for all five habitats.

\begin{tabular}{lccccccc}
\hline \multirow{2}{*}{ BANCHINAE } & & $\begin{array}{c}\text { Cork-oak } \\
\text { woodland }\end{array}$ & $\begin{array}{c}\text { Ash } \\
\text { woodland }\end{array}$ & Shrubland & $\begin{array}{c}\text { Pyrenean-oak } \\
\text { woodland }\end{array}$ & Pastureland & Total \\
& Sorensen & 0.154 & 0.424 & 0.545 & 0.286 & 0.444 & 0.552 \\
\multirow{2}{*}{ CREMASTINAE } & Morisita-Horn & 0.695 & 0.355 & 0.361 & 0.467 & 0.595 & 0.543 \\
\hline \multirow{2}{*}{ CRYPTINI } & Sorensen & 0 & 0.222 & 0.571 & 0 & 0.571 & 0.471 \\
& Morisita-Horn & 0 & 0.284 & 0.670 & 0 & 0.991 & 0.586 \\
\hline \multirow{2}{*}{ CTENOPELMATINAE } & Sorensen & 0.182 & 0.050 & 0.417 & 0.214 & 0.629 & 0.462 \\
& Morisita-Horn & 0.016 & 0.080 & 0.179 & 0.098 & 0.512 & 0.299 \\
\hline \multirow{2}{*}{ METOPIINAE } & Sorensen & 0 & 0.250 & 0 & 0.182 & 0 & 0.258 \\
& Morisita-Horn & 0 & 0.113 & 0 & 0.533 & 0 & 0.091 \\
\hline \multirow{2}{*}{ ORTHOCENTRINAE } & Sorensen & 0 & 0 & 0.571 & 0 & 0.500 & 0.500 \\
& Morisita-Horn & 0 & 0 & 0.478 & 0 & 0.335 & 0.304 \\
\hline \multirow{2}{*}{ PIMPLINAE } & Sorensen & 0.556 & 0.783 & 0.353 & 0.100 & 0.800 & 0.773 \\
& Morisita-Horn & 0.521 & 0.199 & 0.128 & 0.176 & 0.575 & 0.371 \\
\hline \multirow{2}{*}{ TERSILOCHINAE } & Sorensen & 0.286 & 0 & 0.333 & 0.143 & 0.625 & 0.564 \\
& Morisita-Horn & 0.318 & 0 & 0.489 & 0.059 & 0.496 & 0.378 \\
\hline \multirow{2}{*}{ TRYPHONINAE } & Sorensen & 0.400 & 0.167 & 0.222 & 0.714 & 0.429 & 0.690 \\
& Morisita-Horn & 1 & 0.332 & 0.442 & 0.986 & 0.120 & 0.940 \\
\hline \multirow{2}{*}{} & Sorensen & 0 & 0.286 & 0 & 0.400 & 0 & 0.267 \\
& Morisita-Horn & 0 & 0.026 & 0 & 0.400 & 0 & 0.015 \\
\hline
\end{tabular}


the shrubland was significantly higher than in the Pyrenean-oak woodland.

A great percentage of the species were caught by both trapping methods in pastureland (Table 4). However, catches for the shrubland included the highest percentage of species only caught by Moericke traps. In the remaining habitats, the richness assessed by Malaise traps was clearly higher, except for the subfamily Orthocentrinae, which were the richest in terms of species caught by the attraction traps. The relationship between abundance and richness is well represented by a logarithmic function (Fig. 6). With increase in the total catch, the rate of capture of new species slowed down, because the common species make up a large percentage of the total catch, with only few rare species being caught.

\section{Species composition of Ichneumonidae}

Similarities in the species composition of the catches of Ichneumonidae indicated by the Sorensen and MorisitaHorn indices are shown in Table 5 (Anomaloninae and Diplazontinae were not included because few were caught). The Sorensen index, based on presence/absence data, returned higher values than the Morisita-Horn index, which showed relatively low data $(<0.5)$. Thus, the samples caught by both trapping methods differed less in species composition than in the numbers caught. The few cases with a nearly total overlap were for those catches that shared the abundant species. Moreover, the yellow pan trap attracted Ichneumonidae differentially regarding the different species. Orthocentrinae were clearly more abundant in Moericke catches, although a high percentage of rare species were present in the catches of both types of trap.

\section{DISCUSSION}

\section{Replication and sampling effort}

The high variability in most habitats and low richness estimates suggest that more than two replicates of both types of traps are needed to catch most of the species. However, a high percentage of species was sampled when using both Malaise and Moericke traps, reaching nearly $80 \%$ of the projected total species. This percentage is similar to the $75 \%$ obtained by Skillen et al. (2000) during two year study, and the $77-88 \%$ obtained by Sääksjärvi et al. (2004) in the study of a Peruvian tropical forest. Fraser et al. $(2007,2008)$ suggest that even if the sampling effort is increased, it is not possible to catch all the species of Ichneumonidae in an area because singletons will still appear in the catches. Over short periods, common species are rather well sampled, being very useful for long term monitoring. But to achieve a nearly complete checklist of Ichneumonidae for a specific area at a particular time, long and intensive periods of sampling using a combination of different trapping methods are needed (Noyes, 1989; Leirana-Alcocer \& GonzálezMoreno, 2007; Fraser et al., 2008). In an extremely diverse group such as the Ichneumonidae, the presence of rare species produces marked differences in the indices of abundance and richness of species caught by Malaise traps in a particular habitat, even for those caught by adjacent traps (Sääksjärvi et al., 2004; Fraser et al., 2007). However, their high mobility might link them more likely to the vegetation at a mesoscale level or, even more, at the lansdcape level (Fraser et al., 2008).

\section{Abundances}

Malaise traps were significantly more effective for collecting Ichneumonidae than Moericke yellow traps, as previously reported for other surveys of this group (Darling \& Packer, 1988; Noyes, 1989). The yellow pan trap worked better in open habitats, like the pastureland and shrubland. It is possible that the wider field of vision in open areas results in yellow traps attracting insects from greater distances and, hence, a higher catch of insects. Similar results are recorded by Noyes (1989), who caught fewer Hymenoptera in dense forests than in areas with more open vegetation, using yellow pan traps. On the other hand, Malaise traps were more effective in ashwoodland where the presence of a permanent stream running through the habitat acted as a corridor, allowing flying insects to pass from one habitat to another. The low effectiveness in shrubland may be caused by its nearly impenetrable shrubby layer. For effective sampling, Malaise traps should be erected intersecting natural flight paths (Noyes, 1989), but such paths are hard to find in habitats consisting of dense vegetation.

Moericke yellow traps attracted disproportionately more Orthocentrinae than other groups. It is not clear why Hymenoptera are attracted by yellow, even the pollinators as bee species that are not attracted to yellow flowers are caught by yellow pan traps (Monsevičius, 2004). It is possible that larger Hymenoptera are attracted by the water in the trap, especially in dry climates (Day, in Noyes, 1989), but Orthocentrinae are small and probably less affected by a shortage of water.

Annual trends in the numbers of Ichneumonidae caught by both types of trap indicate a peak in spring and another in autumn. This is usual in the Mediterranean area: the autumn maximum consists possibly of individuals about to hibernate which take advantage of any improvement in weather conditions and undertake short flights (Anento \& Selfa, 1997b). In our case, it is more likely to be associated with peaks in rainfall in spring and autumn, which stimulate plant growth that favours insect activity. In continental environments, however, there is usually only one peak in activity, which occurs between spring and early summer (Nieves-Aldrey \& Rey, 1991).

In general, the sex ratio was biased towards females, regardless of trap type, which is commonly reported for Ichneumonidae (Kumagai \& Graf, 2000). Resh \& Cardé (2003), however, suggest that in solitary parasitoids the sex ratio overall is more or less equal.

\section{Species richness}

According to the Malaise trap catches, the highest species richness occurred in ash and Pyrenean-oak woodland, both deciduous forests, while the Moericke trap catches in the shrubland were fairly higher than in the latter, with confidence intervals more than 300 species 
wide. This means that trap type not only influenced the number caught but also species richness.

The Ichneumonidae caught by each kind of trap differed, especially in the relative numbers of the most common species. Campbell \& Hanula (2007) observed that the pollinating insects caught by both Moericke and Malaise traps were fairly similar, but both these traps were positioned $0.5 \mathrm{~m}$ above the ground, so were expected to catch similar insects.

\section{CONCLUSION}

It is assumed that Malaise traps are an effective and standardised way of collecting insects because they do not depend on attraction but on interception, so that all insects flying near ground have the same probability of being caught in areas where the canopy level is not very high, and therefore, the fauna is similar to that at ground level. The effectiveness of Moericke traps in contrast obviously depends on the response of each group to this type of trap and the results are likely to depend on the structure of the habitat and the insect group studied. Thus, for ecological surveys, Malaise traps are the best since they are more likely to reflect the fauna of a specific area. Moericke trap samples could be biased, depending on this attractiveness to different groups of insects (Monsevičius, 2004). However, for inventory purposes, the use of a variety of sampling methods is recommended, especially when highly diverse groups are being sampled (Noyes, 1989; Longino \& Colwell, 1997; Longino et al., 2002; Fraser et al., 2007, 2008; Moreno et al., 2008;). Using a combination of methods is more likely to result in all the potential niches being sampled, and minimize the bias caused by rare species whose rarity is due to methodological shortcomings (Longino et al., 2002).

ACKNOWLEDGEMENTS. We are indebted to G. Broad, curator of the Hymenoptera collection of the Natural History Museum (London, UK), to M. Wilson, head of entomology section of the National Museum of Wales (Cardiff, UK) and to L. Cadahía for their valuable comments on this manuscript. Our special thanks to A. Juan (CIBIO, Alicante University, Spain) for the botanical characterisation of habitats. We also want to express our grateful appreciation to the staff of Cabañeros National Park for providing us with facilities and permissions to collect material in this protected area. This research was supported by Project 040/2002 of the Spanish Ministerio de Medio Ambiente.

\section{REFERENCES}

Anento J.L. \& Selfa J. 1997a: Primeros datos sobre la fauna de Ichneumoninae (Hymenoptera, Ichneumonidae) en tres Parques Naturales de la Comunitat Valenciana. Ecología 11: 501-509.

Anento J.L. \& Selfa J. 1997b: Aproximación al conocimiento de los Ichneumoninae (Hymenoptera: Ichneumonidae) de las sierras de la Calderona y de Peñagolosa. Bol. Asoc. Esp. Entomol. 21: 127-139.

Braud R., Smith D.R., Strazanac J.S. \& Butler L. 2003: Diversity, abundance, and seasonality of adult and larval Symphyta (Hymenoptera) in the George Washington National Forest, Virginia, and the Monongahela National Forest, West Virginia. Proc. Entomol. Soc. Wash. 105: 756-768.
Campbell J.W. \& Hanula J.L. 2007: Efficiency of Malaise traps and colored pan traps for collecting flower visiting insects from three forested ecosystems. J. Insect Conserv. 11: 399-408.

Campos W.G., Pereira D.B.S. \& Schoereder J.H. 2000: Comparison of the efficiency of flight-interception trap models for sampling Hymenoptera and other insects. An. Soc. Entomol. Brasil 29: 381-389.

Colwell R.K. 2005: EstimateS: Statistical Estimation of Species Richness and Shared Species from Samples. Version 7.5. User's Guide and application published at: http://viceroy.eeb. uconn.edu/estimates.

Darling D.C. \& Packer L. 1988: Effectiveness of Malaise traps in collecting Hymenoptera: the influence of trap design, mesh size and location. Can. Entomol. 120: 787-796.

Delfín H. \& Burgos D. 2000: Los Bracónidos (Hymenoptera: Braconidae) como grupo parámetro de biodiversidad en las selvas deciduas del trópico: una discusión acerca de su posible uso. Acta Zool. Mex. 79: 43-56.

Duviar D. \& Pollet A. 1973: Spatial and seasonal distribution of Diptera, Homoptera, and Hymenoptera in a moist shrub savanna. Ecological behaviour of winged insect populations in the savannas of Ivory Coast I. Oikos 24: 42-57.

Fraser S.E.M., Dytham C. \& Mayhew P.J. 2007: Determinants of parasitoid abundance and diversity in woodland habitats. $J$. Appl. Ecol. 44: 352-361.

Fraser S.E.M., Dytham C. \& MaYhew P.J. 2008: The effectiveness and optimal use of Malaise traps for monitoring parasitoid wasps. Insect Conserv. Divers. 1: 22-31.

Ganho N.G. \& Marinoni R.C. 2003: Fauna de Coleoptera no Parque Estadual de Vila Velha, Ponta Grossa, Paraná, Brasil. Abundância e riqueza das famílias capturadas através de armadilhas malaise. Revta Bras. Zool. 20: 727-736.

García V. (ed.) 1997: Parque Nacional de Cabañeros. Ecohábitat, Madrid, $410 \mathrm{pp}$.

Grissell E.E. 1999: Hymenopteran biodiversity: some alien notions. Am. Entomol. 45: 235-244.

HILSZCZAŃSKI J. 1998: The effect of pesticides applied aerially to forest stands on four species of native Hymenopterous parasitoids. In McManus M.L. \& Liebhold A.M. (eds): Proceedings: Population Dynamics, Impacts, and Integrated Management of Forest Defoliating Insects. USDA Forest Service General Technical Report NE-247, pp. 116-121.

Jiménez-Valverde A., Martín Cano J. \& Munguira M.L. 2004: Patrones de diversidad de la fauna de mariposas del Parque Nacional de Cabañeros y su entorno (Ciudad Real, España central) (Lepidoptera, Papilionoidea, Hesperioidea). Anim. Biodiv. Conserv. 27(2): 15-24.

Kitching R.L., Li D. \& Stork N.E. 2001: Assessing biodiversity "sampling packages": how similar are arthropod assemblages in different tropical rainforests? Biodiv. Conserv. 10: 793-813.

Kumagai A.F. \& Graf V. 2000: Ichneumonidae (Hymenoptera) de áreas urbana e rural de Curitiba, Paraná, Brasil. Acta Biol. Par. (Curitiba) 29: 153-168.

Kumagal A.F. \& Graf V. 2002: Biodiversidade de Ichneumonidae (Hymenoptera) e monitoramento das espécies de Pimplinae e Poemenilinae do Capão da Imbuia, Curitiba, Paraná. Revta Bras. Zool. 19: 445-452.

Laubertie E.A., Wratten S.D. \& Sedcole J.R. 2006: The role of odour and visual cues in the pan-trap catching of hoverflies (Diptera: Syrphidae). Ann. Appl. Biol. 148: 173-178.

Leirana-Alcocer J. \& GonzÁlez-Moreno A. 2007: Comparación de dos tipos de trampas en estudios de diversidad de Bracónidos (Hymenoptera: Braconidae) de Yucatán. Entomol. Mex. 6: 332-336. 
Longino J.T. \& Colwell R.K. 1997: Biodiversity assessment using structured inventory: capturing the ant fauna of a tropical rain forest. Ecol. Appl. 7: 1263-1277.

Longino J.T., Coddington J. \& Colwell R.K. 2002: The ant fauna of a tropical rain forest: estimating species richness three different ways. Ecology 83: 689-702.

Marcos-García M.A. 2004: Métodos de captura. In Barrientos J.A. (ed.): Curso Práctico de Entomología. Asociación Española de Entomología; CIBIO Centro Iberoamericano de la Biodiversidad, Universidad de Alicante; Universitat Autònoma de Barcelona, Servei de publicacions, pp. 27-45.

Marinoni R.C. \& Dutra R.R.C. 1997: Famílias de Coleoptera capturadas com armadilha Malaise em oito localidades do estado do Paraná, Brasil. Diversidades alfa e beta. Revta Bras. Zool. 14: 751-770.

Matthews R.W. \& Matthews J.R. 1970: Malaise trap studies of flying insects in a New York Mesic Forest I. Ordinal composition and seasonal abundance. N. Y. Entomol. Soc. 78: 52-60.

Moericke V. 1950: Über das Farbsehen der Pfirsichblattlaus (Myzodes persicae Sulz.). Z. Tierpsychol. Beih. 7: 265-274.

Moericke V. 1951: Eine Farbfalle zur Kontrolle des Fluges von Blattläusen, insbesondere der Pfirsichblattlaus, Myzodes persicae (Sulz.). Nachr. Dt. Pflanzensch. 3: 23-24.

Monsevičıus V. 2004: Comparison of three methods of sampling wild bees (Hymenoptera, Apoidea) in Čepkeliai Nature Reserve (South Lithuania). Ekologija 4: 32-39.

Moreno C.E. \& Halffter G. 2000: Assessing the completeness of bat biodiversity inventories using species accumulation curves. J. Appl. Ecol. 37: 149-158.

Moreno C.E., Guevara R., Sánchez-Rojas G., Téllez D. \& VERDÚ J.R. 2008: Community level patterns in diverse systems: a case study of litter fauna in a Mexican pine-oak forest using higher taxa surrogates and re-sampling methods. Acta Oecol. 33: 73-84.

Nieves-Aldrey J.L. \& Rey del Castillo C. 1991: Ensayo preliminar sobre la captura de insectos por medio de una trampa "Malaise" en la Sierra de Guadarrama (España) con especial referencia a los himenópteros (Insecta, Hymenoptera). Ecología 5: 383-403.

NoYes J.S. 1989: A study of five methods of sampling Hymenoptera (Insecta) in a tropical rainforest, with special reference to the Parasitica. J. Nat. Hist. 23: 285-298.

Onody H.C. \& Penteado-Dias A.M. 2002: Ocorrência dos Ophioninae (Hymenoptera: Ichneumonidae) em área de Caatinga, Rio Grande do Norte, Brasil. Arq. Inst. Biol. São Paulo (Supl.) 69: 306 pp.
Resh V.H. \& CARdÉ R.T. 2003: Encyclopedia of Insects. Academic Press, San Diego, 1266 pp.

Ricarte A. \& Marcos-García M.A. 2008: Hoverflies (Diptera: Syrphidae) of Cabañeros National Park (Spain): a tool for the management. Boln. Asoc. Esp. Entomol. 32(1-2): 19-32.

SäÄKsJärvi I.E., Haataja S., Neuvonen S., Gauld I.D., Jussila R., SAlo J. \& Burgos A.M. 2004: High local species richness of parasitic wasps (Hymenoptera: Ichneumonidae; Pimplinae and Rhyssinae) from the lowland rainforests of Peruvian Amazonia. Ecol. Entomol. 29: 735-743.

SAWONIEWICZ J. 1986: Structure of Ichneumonidae (Hymenoptera) communities in urban green areas of Warsaw. Memor. Zool. 41: 103-139.

SAwONIEWICZ J. 1995: Diversification of communities of Ichneumoninae (Hymenoptera: Ichneumonidae) of canopies of pines during secondary succession of the pine forest of Puszcza Białowieska. Fragm. Faun. 38: 435-445.

Selfa J., Motilla F., Ribes A., Roselló J. \& Domínguez A. 2003: Abundancia de los órdenes de insectos en cuatro sistemas agronómicos mediterráneos. Phytoma Esp. 151: 24-30.

Siegel S. \& Castellan N.J. 1988: Nonparametric Statistics for the Behavioral Sciences. McGraw-Hill, New York, 399 pp.

Skillen E.L., Pickering J. \& Sharkey M.J. 2000: Species richness on the Campopleginae and Ichneumoninae (Hymenoptera: Ichneumonidae) along a latitudinal gradient in Eastern North American old-growth forests. Env. Entomol. 29: 460-466.

Souza L. \& CAmpos M.J.O. 2008: Composition and diversity of bees (Hymenoptera) attracted by Moericke traps in an agricultural area in Rio Claro, state of Sao Paulo, Brasil. Iheringia (Zool.) 98: 236-243.

Steinbauer M.J., Edwards P.B., Hoskins M., Schatz T. \& ForNo W. 2000: Seasonal abundance of insect biocontrol agents of Mimosa pigra in the Northern Territory. Aust. J. Entomol. 39: 328-335.

Townes H. 1972: A light-weight Malaise trap. Entomol. News 83: $239-247$.

Vas J., Markó V., Ábrahám L. \& Mészáros Z. 2001: Study of Neuropteroidea (Raphidioptera, Neuroptera) communities by using Malaise traps in an untreated orchard and its environment. Acta Phytopathol. Entomol. Hungar. 36: 115-122.

Received April 19, 2008; revised September 15, 2008 
APPENDIX 1. Absolute (bold) and relative (normal, in \%) numbers of individuals of all subfamilies caught in each habitat by each trapping method. $\mathrm{M}=$ Malaise trap; $\mathrm{Mo}=$ Moericke trap.

\begin{tabular}{|c|c|c|c|c|c|c|c|c|c|c|c|c|c|}
\hline & \multicolumn{2}{|c|}{$\begin{array}{l}\text { Cork-oak } \\
\text { woodland }\end{array}$} & \multicolumn{2}{|c|}{ Ash woodland } & \multicolumn{2}{|c|}{ Shrubland } & \multicolumn{2}{|c|}{$\begin{array}{l}\text { Pyrenean-oak } \\
\text { woodland }\end{array}$} & \multicolumn{2}{|c|}{ Pastureland } & \multicolumn{3}{|c|}{ Total } \\
\hline & $\mathrm{M}$ & Mo & $\mathrm{M}$ & Mo & $\mathrm{M}$ & Mo & $\mathrm{M}$ & Mo & $\mathrm{M}$ & Mo & $\mathrm{M}$ & Mo & Both \\
\hline \multirow{2}{*}{ Acaenitinae } & 0 & $\mathbf{0}$ & 4 & 0 & 9 & 0 & 0 & 0 & 1 & $\mathbf{0}$ & 14 & 0 & 14 \\
\hline & 0 & 0 & 0.10 & 0 & 0.70 & 0 & 0 & 0 & 0.07 & 0 & 0.13 & 0 & 0.11 \\
\hline \multirow{2}{*}{ Anomaloninae } & 4 & 0 & 60 & 3 & 9 & 1 & 8 & $\mathbf{0}$ & 8 & $\mathbf{0}$ & 89 & 4 & 93 \\
\hline & 0.26 & 0 & 1.54 & 1.55 & 0.70 & 0.30 & 0.28 & 0 & 0.55 & 0 & 0.80 & 0.27 & 0.74 \\
\hline \multirow{2}{*}{ Banchinae } & 98 & 4 & 998 & 20 & 184 & 21 & 516 & 33 & 14 & 15 & 1937 & 94 & 2031 \\
\hline & 6.28 & 5.33 & 25.62 & 10.31 & 14.44 & 6.63 & 18.00 & 17.55 & 9.58 & 2.10 & 17.50 & 6.26 & 16.16 \\
\hline \multirow{2}{*}{ Campopleginae } & 129 & 15 & 1197 & 27 & 516 & 61 & 340 & 25 & 143 & 82 & 2325 & 210 & 2535 \\
\hline & 8.26 & 20.00 & 30.73 & 13.92 & 40.28 & 18.37 & 11.86 & 13.30 & 9.78 & 11.48 & 21.01 & 13.98 & 20.17 \\
\hline \multirow{2}{*}{ Cremastinae } & 1 & 2 & 39 & 1 & 19 & 2 & 4 & 0 & 71 & 2 & 135 & 7 & 142 \\
\hline & 0.06 & 2.67 & 1.03 & 0.52 & 1.48 & 0.60 & 0.14 & 0 & 4.86 & 0.28 & 1.22 & 0.47 & 1.13 \\
\hline \multirow[b]{2}{*}{ Cryptinae } & 396 & 21 & 867 & 57 & 383 & 86 & 766 & 56 & 787 & 314 & 3199 & 534 & 3733 \\
\hline & 25.37 & 28 & 22.26 & 29.38 & 29.90 & 25.90 & 26.72 & 29.79 & 53.83 & 43.98 & 28.91 & 35.55 & 29.70 \\
\hline \multirow{2}{*}{ Ctenopelmatinae } & 1 & $\mathbf{0}$ & 256 & 11 & 5 & 1 & 22 & 7 & 11 & 4 & 295 & 23 & 318 \\
\hline & 0.06 & 0 & 6.57 & 5.67 & 0.39 & 0.30 & 0.77 & 3.72 & 0.75 & 0.56 & 2.67 & 1.53 & 2.53 \\
\hline \multirow{2}{*}{ Diplazontinae } & 2 & $\mathbf{0}$ & 30 & 0 & 0 & 0 & 47 & $\mathbf{0}$ & 2 & 1 & 81 & 1 & 82 \\
\hline & 0.13 & 0 & 0.77 & 0 & 0 & 0 & 1.64 & 0 & 0.14 & 0.14 & 0.73 & 0.07 & 0.65 \\
\hline \multirow{2}{*}{ Eucerotinae } & 0 & $\mathbf{0}$ & 0 & 0 & 0 & 1 & 0 & $\mathbf{0}$ & $\mathbf{0}$ & $\mathbf{0}$ & 0 & 1 & 1 \\
\hline & 0 & 0 & 0 & 0 & 0 & 0.07 & 0 & 0 & 0 & 0 & 0 & 0.07 & 0.01 \\
\hline \multirow{2}{*}{ Ichneumoninae } & 27 & 7 & 93 & 13 & 24 & 28 & 122 & 17 & 78 & 73 & 344 & 138 & 482 \\
\hline & 1.73 & 9.33 & 2.39 & 6.70 & 1.87 & 8.43 & 4.26 & 9.04 & 5.34 & 10.22 & 3.11 & 9.19 & 3.84 \\
\hline \multirow{2}{*}{ Mesochorinae } & $\mathbf{0}$ & $\mathbf{0}$ & 34 & 2 & 6 & 7 & 1 & 3 & 1 & 4 & 42 & 16 & 58 \\
\hline & 0 & 0 & 0.87 & 1.03 & 0.47 & 2.11 & 0.03 & 1.60 & 0.07 & 0.56 & 0.38 & 1.07 & 0.46 \\
\hline \multirow{2}{*}{ Metopiinae } & 25 & 0 & 8 & 1 & 24 & 4 & 57 & 2 & 7 & 4 & 122 & 11 & 133 \\
\hline & 1.60 & 0 & 0.23 & 0.52 & 1.87 & 1.20 & 2.00 & 1.06 & 0.48 & 0.56 & 1.10 & 0.73 & 1.06 \\
\hline \multirow{2}{*}{ Ophioninae } & 6 & 4 & 14 & 0 & 5 & 0 & 4 & 1 & 39 & 0 & 68 & 5 & 73 \\
\hline & 0.38 & 5.33 & 0.36 & 0 & 0.39 & 0 & 0.14 & 0.53 & 2.67 & 0 & 0.61 & 0.33 & 0.58 \\
\hline \multirow{2}{*}{ Orthocentrinae } & 56 & 14 & 65 & 53 & 15 & 81 & 190 & 3 & 59 & 171 & 386 & 325 & 711 \\
\hline & 3.59 & 18.67 & 1.67 & 27.32 & 1.25 & 25.30 & 6.63 & 1.60 & 4.04 & 23.95 & 3.49 & 21.64 & 5.66 \\
\hline \multirow{2}{*}{ Orthopelmatinae } & $\mathbf{0}$ & $\mathbf{0}$ & $\mathbf{0}$ & $\mathbf{0}$ & $\mathbf{0}$ & 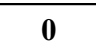 & 2 & 0 & ( & 0 & 2 & 0 & 2 \\
\hline & 0 & 0 & 0 & 0 & 0 & 0 & 0.07 & 0 & 0 & 0 & 0.02 & 0 & 0.02 \\
\hline \multirow{2}{*}{ Pimplinae } & 7 & 3 & 51 & 4 & 25 & 27 & 89 & 1 & 78 & 28 & 251 & 64 & 315 \\
\hline & 0.45 & 4 & 1.31 & 2.06 & 1.95 & 8.13 & 3.14 & 0.53 & 5.34 & 4.06 & 2.27 & 4.26 & 2.51 \\
\hline & 808 & 5 & 82 & 1 & 51 & 4 & 696 & 31 & 36 & 9 & 1673 & 50 & 1723 \\
\hline ae & 51.76 & 6.67 & 2.11 & 0.52 & 3.98 & 1.20 & 24.28 & 16.49 & 2.46 & 1.26 & 15.12 & 3.33 & 13.71 \\
\hline & 1 & 0 & 94 & 1 & 2 & 1 & 2 & 8 & 1 & 5 & 100 & 15 & 115 \\
\hline Tryph & 0.06 & 0 & 2.41 & 0.52 & 0.16 & 0.30 & 0.07 & 4.26 & 0.07 & 0.70 & 0.90 & 1 & 0.92 \\
\hline & 0 & 0 & 1 & 0 & 2 & 3 & 0 & 1 & 0 & 1 & 3 & 5 & 8 \\
\hline Xoridinae & 0 & 0 & 0.03 & 0 & 0.16 & 0.90 & 0 & 0.53 & 0 & 0.14 & 0.03 & 0.33 & 0.06 \\
\hline Total & 1561 & 75 & 3895 & 194 & 1281 & 332 & 2867 & 188 & 1462 & 714 & 11215 & 1534 & 12748 \\
\hline
\end{tabular}

